ARTIGOS 



\title{
ON THE HOMERIC HYMNS AND PRAYER
}

Alejandro Abritta*

RESUMO: O objetivo deste artigo é estudar a possível relação entre a súplica e os Hinos homéricos longos. A análise centra-se no princípio e no fim de composições desse tipo, nas quais duas das partes tradicionais da súplica são encontradas. $\mathrm{O}$ artigo inicia com uma breve exposição do problema, seu objetivo e metodologia. Em seguida, após uma introdução geral sobre os hinos e as súplicas, o autor analisa dois hinos, o Hino homérico ao Apolo Délio e o Hino homérico a Hermes, de modo a mostrar que há neles um desenvolvimento do início, a invocatio, e do fim, o pedido. O objetivo é provar que há uma intencional expansão dos elementos básicos dessas seções e, assim, que esses poemas eram de fato composiçôes ligadas ao culto, destinadas a obter a benevolência ( $\chi \alpha ́ \rho ı s)$ dos deuses.

PALAVRAS-CHAVE: Himnodia, súplica, Hinos Homéricos, Apolo, Hermes.

\section{OS HINOS HOMÉRICOS E A SÚPLICA}

\begin{abstract}
The purpose of this paper is to study the possible relation between prayer and the long Homeric Hymns. The analysis centers on the beginnings and endings of these compositions, in which two of the traditional parts of prayer are found. The paper opens with a brief account of the problem, its goals and methodology. Then, after a general introduction on hymnody and prayer, the author analyzes two hymns, the Homeric Hymn to Delian Apollo and the Homeric Hymn to Hermes, in order to show that in these compositions there is a development of the beginning, the invocatio, and of the ending, the request. The goal is to prove that there is an attentive expansion of the basic elements of these sections, and therefore that these poems were actual cultic compositions to achieve the good will (xápıs) of the gods.
\end{abstract}

KEYWORDS: Hymnody, prayer, Homeric Hymns, Apollo, Hermes. 
${ }^{1}$ For example, Leduc (2005) and Calame (2011).

Throughout this paper, I will use "religious" mainly as a synonym of "cultic" or "ritual", which is problematic in general, but probably not so much when studying hymnody.

Note, however, that an approach like Clay's (in particular, in Clay 2012), who considers Homeric Hymns as "theological" can be considered religious, but clearly not cultic. I shall not deal here with the problem of for which specific cult each hymn was composed. My concern is with the nature of the

Homeric Hymns as compositions, not with their actual performance. The works of Leduc and Calame can be consulted on the subject.

${ }^{2}$ E. g., Furley (1995, 29-30); and Furley and Bremer (2001, 1.1-49, esp. 15). This approach can be traced at least to Allen and Sikes (1904, lv-lxiii).

3 Bremer (1981, 212).

${ }^{4}$ There are two main positions on how should we define "hymn", the one that considers them prayers, which I will use here, and the one that considers them "praises to the gods" (the most important exponent of this position is Pulleyn 1997 and the best sum of the debate I know is in Van den Berg 2001, 13-18). I shall not deal with this problem here, but I think it is only in a later stage of development when

hymnody lost contact with its origins in prayer and therefore lost its last

\section{INTRODUCTION}

$\mathrm{T}$

he Homeric Hymns have in current scholarship a peculiar status within hymnody. Some scholars study them as actual representatives of religious song, and therefore seek their occasion and cultic value. ${ }^{1}$ Others consider them "rhapsodic", or "literary" hymns, ${ }^{2}$ and oppose them to what is called "cult" hymnody, which consists mainly in the for the most part poorly preserved lyric hymns (e.g. Pindar' Paeans). The names selected for the classification are clear indicators that this distinction is not merely metrical: the scholars who use it believe that hexametric hymns in general had little or no religious importance, since they "had never been in actual use in Greek cults". ${ }^{3}$ I believe that the assumption behind this idea is that the Homeric Hymns were not actual prayers or praises to the gods, as proper hymns should be, ${ }^{4}$ but mere tales of the gods, disguised with a formal introduction and ending. There is, indeed, some evidence to support this notion: the Homeric Hymns, as they are usually analyzed, show a marginalization of two of the three traditional parts of hymnody and prayer, which are apparently limited to two or three lines in the introduction and one to three final verses. 5 Since actual hymns are, since Antiquity, "sung prayers", ${ }^{6}$ such a marginalization can be interpreted, as some scholars do, as a reason to exclude those texts from "actual" hymns. ${ }^{7}$ However, the Ancients classified them as hymns together with their lyric counterparts, and there is little evidence that a division existed in any way in Antiquity. ${ }^{8}$

A formal analysis of the Homeric Hymns has led María Paz de $\mathrm{Hoz}^{9}$ to consider short Homeric Hymns as actual prayers. Their (other-than-metrical) exclusion from lyric hymns is, therefore, difficult to substantiate. Nevertheless, long hymns are still excluded, since they are apparently only concerned with narration. The purpose of this paper is to challenge this idea. By focusing on the strategies the poets use to emphasize the openings and closings of their hymns, I intend to show that they are actually quite engaged in achieving the main religious goals of prayer, namely, obtaining the good will (xápıs) of the $\operatorname{god}(s)$. This does 
not necessarily mean, as pointed by De Hoz, that they were not "prooemia" to longer poems, such as epics, ${ }^{11}$ but that, whatever their function, their genre was that of any other hymn. The ultimate goal is to support the idea that, while a merely formal distinction between types of hymnody could be useful, a division based on the religious or pragmatical status of hymns is inappropriate.

In order to do this, after a general introduction on the parts of prayer and hymnody, I will focus on two long Homeric Hymns. ${ }^{12} \mathrm{I}$ intend to show that, at least in those two cases in the extant corpus, there is a development of the introduction or the closing of the hymn, which the poets use to boost the efficacy of these sections.

\section{PARTS OF PRAYER AND HYMNODY}

Ancient prayer has at least two main parts: the calling of a god (the invocation or invocatio) and the expression of a wish or of gratitude for a conceded wish (the request or precatio). This is of course the most basic relation between humans and the sphere of divinity: simply to identify one of the many divine powers ${ }^{13}$ and then to ask something of it. Usually, this basic scheme is complicated by the inclusion, between the invocation of the god and the request, of a series of arguments that intend to convince the divinity to grant the requested wish. Pulleyn ${ }^{14}$ has shown that these arguments are part of an intricate system of Xápıs between gods and humans. This implies that the argumentum is not meant simply to convince a god, but to remind him or her of the link between him or her and the speaker. Humans have a number of ways of establishing this connection, but it is mainly through $\alpha \gamma \alpha$ ó $\lambda \mu \alpha \tau \alpha$ (gifts) that they can accomplish it. These gifts are usually sacrifices of some kind, but they can also be promises, libations and other dedications. Eventually, even the way in which people ask for things adapts to this system of reciprocity and develops in order to include a pleasing of the god within the prayer. This pleasing is the song, and these songs are what we call hymns. ${ }^{15}$

However, both in prayers and in hymns clearly derived from prayer the presence of the wish or the gratitude is section. It should also be noted that there is a special kind of prayer that conveys gratitude, which can also be confused with a simple praise (see Versnel 1981, 42-62). What is more, any praise to a god is a way of obtaining his or her xópıs (see the references in n. 10), and therefore, in a sense, any praise is a prayer.

${ }^{5}$ On the parts of hymnody and prayer, see below. The classical reference on the subject is Ausfeld (1903). More modern approaches are De Hoz (1998), Furley and Bremer (2001, 1.5063 ), and Morand (2001, 40-8). Also, particularly concerned with the Homeric Hymns, see Janko (1981).

${ }^{6}$ The definition of "hymn" as "sung prayer" is at least as old as Plato (Rep. 607a and Laws 700b), and has been preserved almost unchanged, to the point that Bremer (1981) provides an almost indistinguishable one (though he puts some emphasis in the performance in cult of a proper hymn).

\footnotetext{
${ }^{7}$ The fact that the definition mentions singing could be use for the same purpose, since hexametric compositions were allegedly not sung but recited. However, besides the fact that this does not seem to have been an important distinction in Antiquity (see, e.g., Silva-Barris 2011, 13-14), scholars agree that these compositions were originally sung, and
} 
only in a latter period recited (see Càssola 1997,

xxii-xxv; and Furley 2007, 129).

Note also that the history of hymnody is not parallel to the history of the words üuvos and ú $\mu \nu \varepsilon \hat{\imath} \nu$, on which see Vergados (2013, 217 218), and Ford (2002, $12)$, with their references.

${ }^{8}$ Of course, I do not pretend to say that the distinction has no basis: there are clear differences between hexametric and nonhexametric hymnody, not only metrical but also of style. My objection is to the virtual exclusion of the first type from the category of "hymns" in its full sense. See Ford (2011, 105-111), who I believe attempts to reach similar conclusions.

9 In De Hoz (1998).

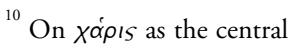
goal of the hymnist, see Race (1982, 8-10), and Furley (2007, 124-127).

${ }^{11}$ See Càssola (1997, xii-xx); Furley and Bremer (2001, 1.41-2); and Faulkner (2011, 16-9). Particularly Càssola and Furley and Bremer have detailed references and discussion about the subject. It should be said that the "preludical" nature of these long hymns has been challenged frequently because of their extension, but rarely the proposed alternatives give them a more important place in cult or religion.

${ }^{12}$ I refer to a distinction made by Torres-Guerra (2002-2003). essential and structural. Rarely do composers of lyric hymns engage in an extensive narration (like those of the long Homeric Hymns), and the central part, when there is a central part, is usually concerned with a direct praise to the god. ${ }^{16}$ As has been mentioned above, that does not happen in the Homeric Hymns. These poems have a request, but usually it is a standardized salutation, without any kind of reference to a particular demand or gratitude. Only the short hymns XI, XIII, XV and XXII, the middle hymns XXX and XXXI and the long Homeric Hymn to Demeter (I leave aside hymn VIII, almost surely misplaced in the corpus) have some sort of specific request to the god, and in most of these cases there is a formulaic repetition in the endings that suggests that it is not a particular prayer for a given situation. There seems to be no real religious intention behind these endings, and they are usually taken as nothing more than the needed closure for the poem.

Something similar can be said of the introduction of the Homeric Hymns. A study on the opening formulae of these poems has led Françoise Létoublon to conclude that they are not actual prayers, since the model of prayer in the Homeric epics always include a direct call to the gods in the second person, while the hymns usually name them in accusative or genitive. ${ }^{17}$ However, there are counterexamples to this tendency (hymns XXI and XXIX) and the direct address to the god is always present at the end of the hymns. ${ }^{18}$ Létoublon's conclusions do not depend exclusively, therefore, on her formal study of the formulae: it rests on the same assumption that lies behind the classification of hexametric hymns as "literary" or "rhapsodic", namely, the fact that the poet is only concerned with the story he wants to tell, and that the beginning and closing of his text is nothing more than an unavoidable concession to the genre of hymnody. ${ }^{19}$ This can be inferred also by the fact that De Hoz, who is aware of the formularity of the opening and closing of hymns, but does not share Létoublon's assumption, reaches a different conclusion in her analysis of the short Homeric Hymns.

The idea I will try to defend is that this assumption should be left aside, and that the Homeric hymnist was 
very much concerned with composing a prayer. In order to do this, in the following sections I will analyze two cases in which I believe he actually develops the beginning and the closing of his poem. ${ }^{20}$ If it could be shown that at least in some cases that does happen, the assumption would be extremely weakened.

\section{AN EXPANDED REQUEST IN THE HOMERIC HYMN TO DELIAN APOLLO}

Though it has been one of the most discussed aspects of the corpus of Homeric Hymns, I shall not treat here the problem of the unity of the Homeric Hymn to Apollo. I believe that at this point enough has been said as to make considerably clear that the hymn we possess is composed of two previous ones: the Delian one and the Delphic one. ${ }^{21}$ Because of this, verses 165-78 of the whole text should be considered the ending of the first hymn: ${ }^{22}$

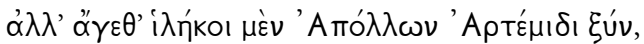

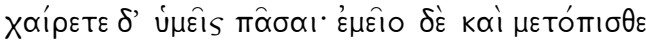

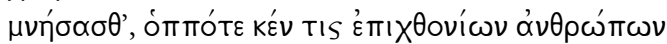

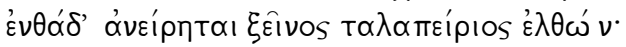

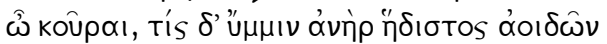

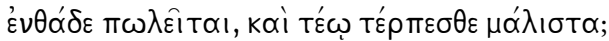

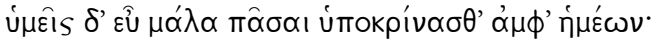

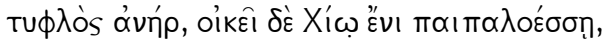

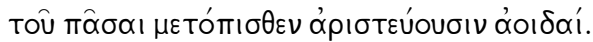

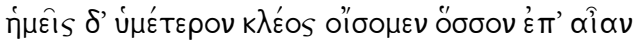

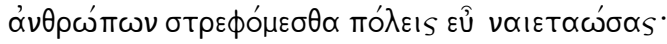

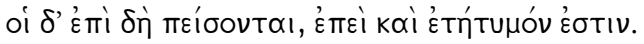

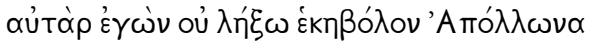

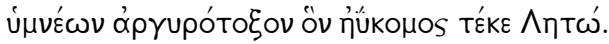

But, come on! may Apollo be favorable with Artemis And farewell all you, [Delian Maidens]! And from now on Remember me whenever any one of the men that inhabit earth, A foreigner coming here after much suffering asks of you: "O, maidens! Which man for you as the sweetest of singers Came here, and in whom do you most delight?" 165

${ }^{13}$ Versnel (1981, 10-16) explains that the need to identify gods is related to polytheism. The same idea in a different context is expressed by Pulleyn (1994).

${ }^{14}$ In Pulleyn (1997, 1-38).

${ }^{15}$ The difference between Bremer (1981) and Pulleyn (1997) positions on hymnody (see n. 5) can be summed up by this statement: while the first one thinks prayer develops into and therefore includes song, the second one considers that songs can include a prayer, but that this does not make them prayers.

${ }^{16}$ Indeed, Furley and Bremer (2001, 56-60), use the term "praise" for the central section.

${ }^{17}$ Létoublon (2012, esp. 26-30).

${ }^{18}$ It should also be noted that De Hoz (1998, 54) mentions lyric hymns that also lack the vocatives at the beginning (for example, Epidaurus' hymn to Pan, PMG 936).

${ }^{19}$ In other words,

175 Létoublon concludes that the Homeric Hymns are not prayers because she has already assumed that they are tales about the gods (which becomes clear in pp. 34-5, the conclusions of her article), and therefore any difference with "actual" prayers must be explained through this notion. I would suggest that there are at least three other explanations, not mutually exclusive, that 
Létoublon does not consider. Firstly, prayers in the epics are always in the second person not because that is an actual condition of prayer, but because the poets assumed that heroes and gods had a close relation, and therefore a direct calling of the god is more appropriate for them than for most humans. Secondly, the influence of epics can be playing an important role in the composition of the Homeric Hymns (which are, after all, hexametric poetry), and inspiring, so

to speak, the poets to identify the celebrated god with their subject matter. Thirdly, the hymns rest on a tradition that considers singing as a form of summoning, since Greeks seem to have believed that gods had to present themselves in order to hear the requests addressed to them (see Versnel 1981, 10-16, and Pulleyn 1994,

13). Consequently, when the singer starts his performance, the god is not there to be addressed directly; he is with the singer, however, after the hymn that attracts him has been sung, and that explains why the request is always in the second person.

${ }^{20}$ I will use "development" and "expansion" in a similar way as they are used in oral studies (see Lord 1971, 99-123).

${ }^{21}$ Miller (1979 and 1986) and Clay (1989) are still the most serious supporters of the unity of the text. Chappell (2011) and Abritta (2012) have a detailed state of the question
"A blind man, and he dwells in rocky Chios,

Whose songs will from now onwards stand out," And we will carry your glory as far as over the earth

We roam to the well-inhabited cities of man;

And they will believe us, for it is true.

But I will not cease to praise far-shooting Apollo

Of the silver bow whom rich-haired Leto bore.

The extension of the quote must of course be the first indicator that there is something odd going on here. Janko takes this whole passage as the conclusion of the Delian Hymn, and points to some of the peculiarities that it shows:

Not only does the poet hail the chorus of Delian girls on the same terms as Apollo (165-6), but he then abandons the usual poetic anonymity to indulge in a sphragis at some length (16676), in place of the prayer usual here in Hymns that end with Attributes. ${ }^{23}$ This is proved by the fact that he includes in the sphragis a request to the maidens to spread his fame, which is no doubt why they receive the Salutation at v. 166. At least he closes with the usual reference to another song (vv. 177-8). ${ }^{24}$

Note the complexity of structure to which this scholar points. There is a request included in a sphragis inserted in a salutation to the Delian Maidens surrounded by a salutation to Apollo and a reference to another song. Is there some logic behind these oddities? One might consider that there is some kind of annular structure here, but the abrupt division between the address to the maidens and the final reference seems to a certain extent to diminish this possibility. At first glance, the only apparent reason for this extended conclusion is the poet's desire of fame.

There is, however, some evidence that there is something more to be said about this passage. Miller ${ }^{25}$ notes that the phrasing ou $\lambda n^{\prime} \xi \omega$ for the final reference to another song is unique in the corpus. By itself, this is not very important (pace Miller), because ou $\lambda \eta^{\prime} \xi \omega . .$. is semantically similar to other more common expressions like $\alpha^{\prime \prime} \lambda \lambda \eta s$

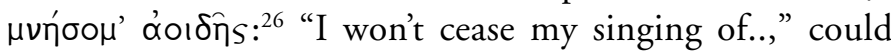
simply mean quite "I will remember another song for..,". The expression, however, allows Mike Chappell, ${ }^{27}$ to bring 
a reference to a hymn to Isis inscribed in a column in Egypt written by one Isidorus (SEG 8. 548). The final verses of this hymn are as compelling as the ones quoted above:

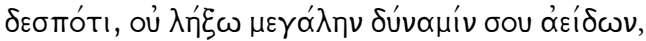

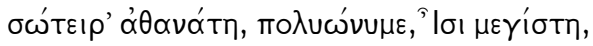

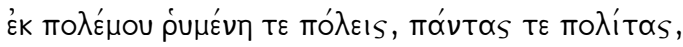

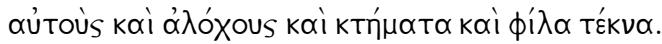

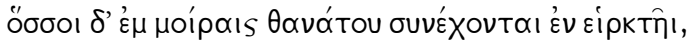

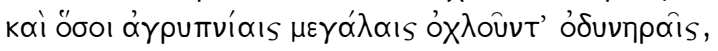

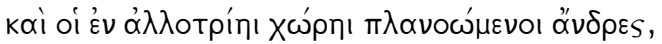

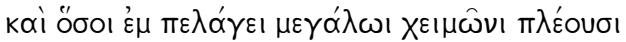

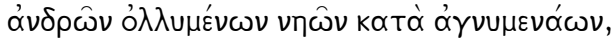

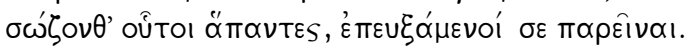

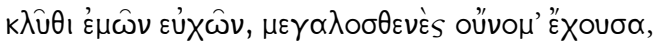

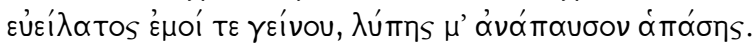

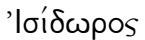
हैүрафє.

Queen, I shall not cease of singing your great power, Immortal savior, of many names, great Isis, Protectress from the war of cities and of all the citizens, Of them, of their wives, of their properties and of [their beloved offspring.

The ones that in the fate of death are trapped in a prison, The ones that suffer in long, painful and sleepless nights And the men who wander in foreign land, And the ones that sail in the great sea in winter, Their men dying under their broken ships, All of these are saved when they pray for your presence. Hear my prayers, [you] who have a name of great power, Arise merciful for me and free me of all pain.

$$
\begin{aligned}
& \text { Isidorus } \\
& \text { Wrote [it]. }
\end{aligned}
$$

As in the Homeric Hymn to Delian Apollo, what can be found here is a long conclusion with a complex structure. Isidorus begins with a reference to another song, and then enumerates some attributes of Isis that become a list of the people who the goddess protects. This list has two parts: the objects of the participle pup'́vn and the subjects of the

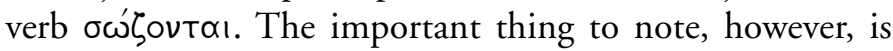
the order of these motives: the beginning of the conclusion and a good enumeration of the arguments against unity. Since it is not important to what is to be said here, I shall not take a position in the complex matter of when and how the two poems were mixed, on which the referred texts expand considerably (see also on the subject Janko 1982, 112-115).

${ }^{22}$ All the references to the Homeric Hymns are from the edition of Càssola (1997).

${ }^{23}$ Janko (1981, 14-15) explains that in some hymns the final part of the middle section (Bremer's argument) is a Prolongation of the myth, which introduces a passage with some attributes of the god. The hymns that have this prolongation usually have all three elements of the conclusion (that is, salutation, prayer and reference to another song).

${ }^{24}$ Janko (1981, 17-18).

${ }^{25}$ In Miller (1979, 178).

${ }^{26}$ Hymns II (v. 495), IIIb (v. 546), III (v. 580), VI (v. 295), etc.

${ }^{27}$ In Chappell $(2011,63)$. 
${ }^{28}$ Actually, in the column where this hymn has been found there is one poem in each of the faces.

${ }^{29}$ In Miller (1979, 182). has a reference to another song ${ }^{28}$ and the ending of it has the request, particularly in this case the request for protection. In the middle of these, there is an expansion of the protective character of the Egyptian goddess. The link of this expansion should not be sought in what precedes it, then, but in what follows it: the request is justified in the hymn by the enumeration of the people protected by Isis. In other words, Isidorus seems to be saying something like "I shall continue singing to you, Isis, and since you protect all men who... protect me also". In this variation of the typical argument in hymns da ut dedisti, a sort of ut dedisti da, the ending of this prayer founds the additional strength that the believer is always seeking in order to convince the god of helping him.

Isidorus' hymn provides a possible solution to the problem of the structure of the ending of the Homeric Hymn to Delian Apollo. If the logic of the ending is sought in reverse, that is, the expansion as an expansion of what follows, not of what precedes it, some clarity seems to appear immediately. The poet inserts his sphragis as a way of reinforcing a typical do ut des, which is expressed in the final two lines of the poem: "Greetings, Apollo; I am the one who will be called the greatest of poets, and I will not stop singing for you". Not only this, but the ones who will remember the poet's name, as has been described in the last part of the myth of Apollo's birth, are the own servants of the god (v. 157), great marvel whose glory shall never perish (v. 156). "The greatest of poets, so declared by the greatest of choruses, will sing for you again, Apollo": that is what this bard is singing.

Within this expansion there is, as Miller suggests, ${ }^{29}$ a sort of miniature hymn to the Delian Maidens. However, this should not be seen as a deviation from the traditional scheme of hymnody: the request and promise to the Maidens is essential to the development of the request and promise to Apollo. The poet needs to be sure, in order to assure the god, that he is going to have a good trading coin for obtaining the good will of the son of Leto. The structure of the closing begins with the salutation of Apollo and ends with the promise to remember another song, within which there is a hymn to the Delian Maidens, which is actually 
an expansion of the last two verses, in order to reinforce their effect on the god.

If this sort of backwards expansion is not peculiar to these couple of hymns but the general strategy for developing the final request in hexametric hymnody, which implies that it can be found in other extant texts, ${ }^{30}$ then we have a tool for exploring how the poets intended to relate with the gods. Notice that in both cases the expansion is not an arbitrary choice of arguments: Isidorus characterizes Isis as the protective goddess par excellence, and Apollo is the god of song and music, whose appearance is directly related in the hymn with the festivals of Delos. ${ }^{31}$ The development of the request in these poems is a development of the peculiar request they are expressing: a final attempt by the hymnist to gain the favor of the god. The sphragis in the Homeric Hymn to Delian Apollo is not a game for the poet, nor is it merely a sign of his inflated ego: it is a fundamental part of the strategy he is using to communicate with the god.

\section{THE LONG INTRODUCTION OF THE HOMERIC HYMN TO HERMES}

The Introduction of the Homeric Hymns has been defined quite properly as "the material down to the first relative pronoun" ${ }^{32}$ It is composed with the same content as any hymnic Invocatio: the name(s) of the god in vocative or accusative and some epithets with a possible reference to a geographical location. ${ }^{33}$ With this in mind, the introduction of the Homeric Hymn to Hermes is nothing if not traditional: ${ }^{34}$

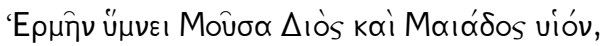

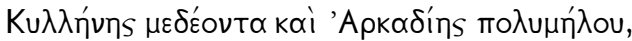

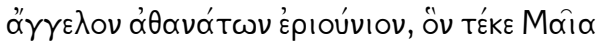

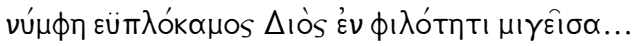

Sing, Muse, of Hermes, the son of Zeus and Maia Lord of Cyllene and Arcadia rich in flocks, Quick messenger of the immortals, whom Maia bore, The rich-tressed nymph, joined in love with Zeus...
${ }^{30}$ There is at least one other possible case in the Orphic Hymn to Apollo (See Abritta 2012, 16-18).

${ }^{31}$ On the relation between poetry, Apollo and Delos, see Kowalzig (2007, 59-80).

32 Janko (1981, 10).

${ }^{33}$ See Bremer (1981, 194-5); Furley and Bremer (2001, 1.52-6); and Calame (2011, 337-41).

${ }^{34}$ This is the opinion of Janko (1981) and Calame (2011, 337-8). 
${ }^{35}$ On Vergados' position on these lines, see below, n. 40 .

The simplest interpretation of the nature of what follows the first three verses is that it is the beginning of the myth of Hermes' birth. ${ }^{35}$ However, some features of the following lines are odd in this view:

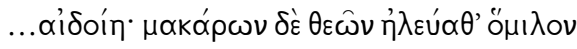
5

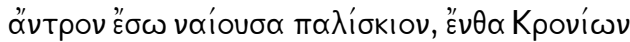

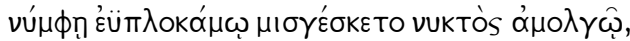

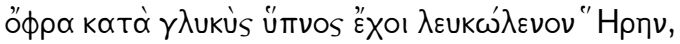

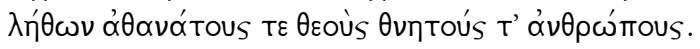

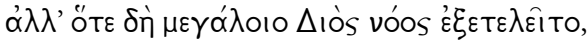
10

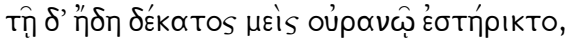

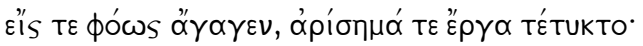

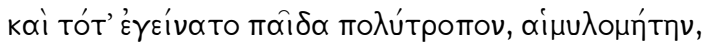

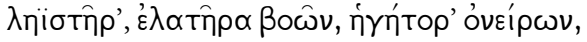

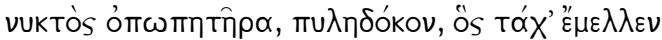

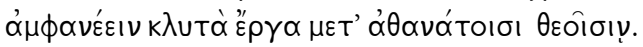

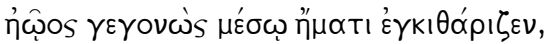

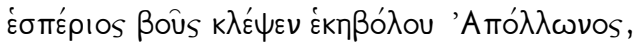

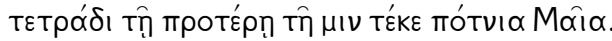

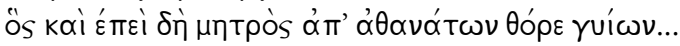

...Shy goddess; she escaped the company of the blessed gods, Inhabiting a shady cave, where the son of Cronos

Laid with the rich-tressed nymph in the dead of night, While sweet sleep held white-armed Hera fast, And hiding from immortal gods and mortal men. But when the purpose of great Zeus was fulfilled, And there the tenth moon was fixed in heaven, She gave birth and notable deeds were produced; And she delivered a son, of many shifts, of wily cunning, Robber, cattle driver, captain of dreams, Watcher of the night, keeper of gates, who soon was to Show forth glorious deeds among the immortal gods. Born with the dawning, at mid-day he played on the lyre, And in the evening he stole the cows of far-shooting Apollo, On the fourth day of the month, day on which venerable [Maia bore him.

As soon as he leaped from his mother's immortal womb...

This beginning has apparently three parts: the story of Hermes conception (5-12), the succession of epithets attributed to him at birth (13-15) and the events of the 
first day of his life (15-19), actually the substance of the myth about to be narrated. ${ }^{36}$ All of these parts can be seen at least to some extent as strange in the context of the mythical section. The first curious thing is that the poet goes back in time from the moment of the birth to the moment of the conception. This is not particularly strange, since other hymns have some kind of regression like this one; ${ }^{37}$ however, in two of the three cases the regression is a central part of the myth (Hymns IIIa and XIX) and in the remaining one (XXXI) it appears to be pointed to describing the genealogy of the god (Helios), which clearly is not the case in the quoted passage. ${ }^{38}$

The second part of this beginning is also odd: in only two other instances in the corpus ${ }^{39}$ there is a succession of epithets and, in both of them, it is placed in the introduction of the poem (that is, before the first relative pronoun). Finally, the proem-like lines are unique to this hymn: in no other case in the corpus does the poet describe in the first verses what he is going to narrate. Indeed, the Homeric Hymn to Hermes probably has the only proem to be found in a hexametric hymn. ${ }^{40}$

The most compelling aspect of this beginning is, however, its gratuitousness: in verse 20 the poet retakes the narration of the story from the moment the god jumps out from the womb. In a way, it is as if lines 3-19 were an exordium, a part of the introduction of the hymn. And this seems to be quite reasonable: the use of the relative pronoun to introduce the myth, almost ubiquitous in the Homeric Hymns, can be taken as proof that the central part of the hymns was developed as an extension of the beginning; therefore, why would the poet not be able to use the same mechanism within a single composition to expand the introduction of an already tripartite poem? In this sense, the Homeric Hymn to Hermes shows a type of expansion, but one different from that found in the Hymn to Delian Apollo: an expansion of the Invocatio, not of the request.

Some additional arguments can be introduced to support this view, the first of which is the other Homeric Hymn to Hermes (XVIII). This 12-verse poem ${ }^{41}$ is almost a copy of the first ten lines of the quoted hymn, but it ends when the conception of Hermes has already been
${ }^{36}$ Vergados (2013, 214), divides the first 19 lines between "Hermes' parentage" (1-9) and "Hermes' Birth" (10-19).

${ }^{37}$ Hymns IIIa (beginning in v. 25), XIX (27-47) and XXXI (2-7). Also, the other Homeric Hymn to Hermes (Hymn XVIII), which I will consider presently.

${ }^{38}$ The mere mention of a god's genealogy cannot be considered an elaboration on it, mainly because in most cases it was standard knowledge to all listeners.

${ }^{39}$ Hymns XIX (vv. 1-2) and XXVIII (vv. 1-4). This second hymn is another interesting case of expanded introduction, which I study elsewhere. Hymn XIX has another succession of epithets in 36-7, at Pan's birth, but the structure of this hymn is very problematic. Vergados (2013, 228), who notes these parallels, mentions also Hymn XXIX (vv.7-8), but there the epithets are not for the recipient of the hymn, and therefore the situation is very different.

${ }^{40}$ Vergados $(2013,125)$, who does not consider the tripartite structure of prayer in his analysis, understands lines $1-19$ as a "Proem" to the hymn. I cannot share this approach, which (as most of his analysis) disregards the hymnic nature of the poem. Note also that the parallels he mentions are from epic, not from hymnody. This is why, while his approach explains the gratuitousness of the beginning of the 
hymn (see the next paragraph), I cannot appeal to it as a proper solution to the problem, although superficially mine resembles his.

${ }^{41}$ Actually, the last three verses seem to be two different endings juxtaposed in the manuscript; see the commentary ad loc in Càssola (1997).

${ }^{42}$ The link between this passage (and others) of the Homeric Hymn to Hermes and the Odyssey is analyzed in Shelmerdine (1986).

${ }^{43}$ A more detailed analysis of the word, different but compatible with what has been said here, in Vergados (2013, 232-233).

${ }^{44}$ There is more to be said about the epithet поגútротоs, since it always occupies the same morae of the line, namely, the ones between the third trochaic caesura and the bucolic dieresis. In the theory presented by David (2006), which locates the origin of the hexameter in a circular and retrogressive Greek dance, the ouptós, those positions correspond exactly with the turn of the dancers in the circle. The placing of поли́ротог, therefore, seems not to be accidental: the epithet that means literally "of-manyturns" is located precisely at the turn of the dance. In personal communication, Dr. David has called my attention, in relation to the analysis of the word поли́тротоs, to the placing of $\pi \alpha \lambda_{\imath} ı v$ and its compounds within the line, which usually occupy the same places. In the accomplished (v. 9 in both poems). That is, it does not reelaborate on the moment of birth: as in any other hymn that tells the story of the origin of a god, it tells the story only once. It is clear that this short poem has a tripartite structure: the first three verses are an invocatio, between verses three and nine there is the myth and the last three verses contain two possible endings. This is another fact that highlights the introduction of the longest hymn of our corpus: it is composed with what is almost a completely independent hymn.

There is another mark of the peculiarity of the quoted passage: the epithet по入и́трото (v. 13). There are only four instances of this word in Archaic hexameter, two of which are in this poem (the other one is in verse 439). The other ones are in the Odyssey (I, 1 and X, 330), attributed to Odysseus (who is a descendant of Hermes). ${ }^{42}$ The epithet means literally "much-turned"; when attributed to Odysseus, LSJ suggest the meaning "much-traveled" and, when attributed to Hermes in the hymn, they suggest "shifty" and "versatile". However, it is clear that Odysseus is as "shifty" and "versatile" as Hermes. What is most likely is that the word has a two-folded sense: it means both that a human or a god is cunning and wily, and that he has many adventures. ${ }^{43}$ This actually accounts very well for the placing of the epithet in the hymn: it is located precisely at a new turn of the poem, the moment where the succession of epithets begins. The poet seems to have placed in the middle of his invocatio an explanation of the need of such a complex introduction: the god called for is a god of many turns, and deserves a many-turned poem. ${ }^{44}$

Finally, there are textual marks that suggest that this expansion is carefully woven in order to link each of its constituent parts with the others. The story of Hermes conception is surrounded by two "births" of the god, in vv.

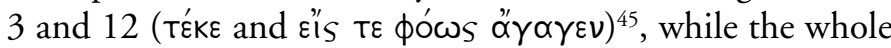
invocatio closes with a third one in v. 19 (тย́kE). The extremes of this expansion are also linked by the presence of Mâa in vv. 3 and 19; the reference to the mother (with a variation in formula) is natural with the mention of the birth. Moreover, the turning points inside the expansion share a reference to time (vv. 11 and 19, which also share adverbial 


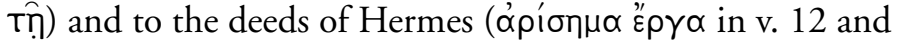

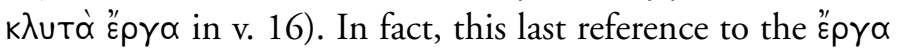
in v. 16 can be understood as the foundation of the "proem" of vv. 15-19:46 the relative sentence with the glorious deeds to be soon accomplished by the god is the last epithet of

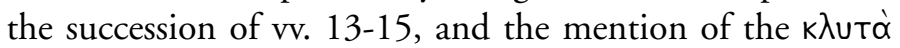
" $p \gamma \alpha$ seems to inspire the poet, so to speak, to expand on the main actions of the myth. ${ }^{47}$ It should be noticed, finally, that this complex development of the different parts of the introduction does not affect the strict order of the sections of the poem as a whole: the myth begins in v. 20 at the same exact moment in which the "loop" of the expansion started, the moment when Hermes leaps from the womb of Maia.

The invocatio of a prayer is particularly important in cultic contexts because polytheism generates the need of identifying carefully the god that is being summoned. ${ }^{48}$ It is perhaps the most ritualistic section of prayer, since a mistake made there could invalidate completely the attempt of the mortal(s) to communicate with the divine. The introduction of the Homeric Hymn to Hermes is a good example of how the hymnist can elaborate on this essential section of his work in order to specify the nature of the god he is calling, not only in the mere sense of the words used ("Hermes, son of Maia, god of many turns, prince of the robbers, that invented the lyre, etc,") but also in the structure of the composition itself: as Hermes, the hymn begins its existence with many turns. It is quite likely that the son of Maia would have been pleased with such a kind of worship.

\section{Conclusion}

By developing the beginning or the ending of their hymns, the poets of the Homeric Hymn to Hermes and to Delian Apollo seem to increase greatly the efficacy of their invocation and request, respectively. In the second case, by including a sphragis that exalts the poet's abilities and fame, the promise he makes to the god of performing another song in the future is made more appealing to Apollo, and
Homeric Hymn to Hermes

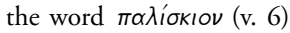
can be mentioned, which actually fills the full space of the retrogression of the dance.

${ }^{45}$ Also notice TÉtukTo at the end of this verse, which presents an appealing phonetic resemblance with some

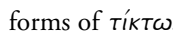

\footnotetext{
${ }^{46}$ As noted by Vergados (2013, 236-7).

${ }^{47}$ The fact that this last epithet of the list that begins with полútропо becomes a proem for the many adventures of Hermes is another reason to think that the adjective means more than simply "versatile".

${ }^{48}$ See the references in note 13 .
} 
therefore the possibilities of gaining his $\chi \alpha$ óp The expansion of the request is not simply a literary device to bring closure to the hymn: it connects what the myth has told about the god (the fact that he is responsible for the festival in Delos) with what is generally in the extant collection a formulaic ending: the promise to sing to him again. By including the salutation and request to the Delian Maidens, the blind man of Chios manages to revitalize, so to speak, the religious strength of the final promise, and therefore to increase the chances of his hymn to accomplish its main goal.

In the Homeric Hymn to Hermes, the expansion of the invocation produces a similar effect with this section of hymnody. When singing to a god of many turns with a many-turned poem, a many-turned introduction is the best way to go. The regression to Hermes' conception, the list of epithets and the proem to the myth both elaborate and symbolize the complicated nature of the god, in an exceptional fusion of form and meaning.

If the methodological assumption made in the second section of this paper is accepted, namely, that a development of traditional aspects of prayers should be read as an association of the poems with that genre, the examples presented can be considered evidence in favor of the claim that the Homeric Hymns were much more than mere preludes to other compositions. The assumption that this proof intended to weaken, namely, that they were only concerned with the telling of a story, and therefore that they were not actual praises and requests to the gods, might still be acceptable. However, it must now deal with the fact that at least in two cases in the corpus there is a development of the parts of prayer it claims were mere formalities, unimportant concessions to the genre of hymnody. Perhaps that may blur the line between hexametric and lyric hymns, and allow us to consider both as equal gifts to the gods. 


\section{BIBLIOGRAPHY}

ABRITTA, A., TORRES, D. A. Perspectivas corales para una lectura de Ilíada. Anales de Filología Clásica, 26, p. 5-18, 2013.

ABRITTA, A. Contribuciones al problema de la unidad del Himno Homérico a Apolo. Argos, v. 35, p. 103-124, 2012.

ABRITTA, A. Sobre la posibilidad de un análisis coral en Ilíada 53-305. Anales de Filología Clásica, v. 23, p. 1-62, 2010.

ALLEN, T. W., SIKES, E. E. The Homeric Hymns. Edited with Preface, Apparatus Criticus, Notes, and Appendices. London: Macmillan, 1904.

AUSFELD, K. De Graecorum precationibus quaestionibus. Jahrbuch für classische Philologie, Supplement Band 28, p. 502-547, 1903.

BREMER, J. M. Greek Hymns. In VERSNEL, H. S. Faith, Hope and Worship: Aspects of Religious Mentality in the Ancient World. Leiden: Brill, 1981. p. 193-215.

CALAME, C. The Homeric Hymns as Poetic Offerings: Musical and Ritual Relationships with the Gods. In FAULKNER, A. (ed.). The Homeric Hymns: Interpretative Essays. Oxford: Oxford University Press, 2011. p. 334-358.

CÀSSOLA, F. Inni Omerici. Milano: Fondazione Lorenzo Valla, $1997^{6}$ [1975].

CHAPPELL, M. The Homeric Hymn to Apollo: The Question of Unity. In FAULKNER, A. (ed.). The Homeric Hymns: Interpretative Essays. Oxford: Oxford University Press, 2011. p. 59-81.

CLAY, J. S. The Politics of Olympus. Princeton: Princeton University Press, 1989.

CLAY, J. S. Theology and Religion in the Homeric Hymns. In BOUCHON, R., BRILLET-DUBOIS, P., WEISSMAN, N. L. M. (eds.). Hymnes de la Grèce Antique: Approches Littéraires et Historiques. Lyon: Maison de l'Orient et de la Méditerranée, 2012. p. 315-322. 
DAVID, A. P. The Dance of the Muses. Oxford: Oxford University Press, 2006.

DE HOZ, M. P. Los himnos homéricos cortos y las plegarias cultuales. Emerita, v. 66, p. 49-66, 1998.

FAULKNER, A. Introduction: Modern Scholarship on the Homeric Hymns: foundational Issues. In FAULKNER, A. (ed.). The Homeric Hymns: Interpretative Essays. Oxford: Oxford University Press, 2011. p. 1-28.

FORD, A. Aristotle as Poet: The Song for Hermias and its Contexts. Oxford: Oxford University Press, 2011.

FORD, A. The Origins of Criticism: Literary Culture and Poetic Theory in Classical Greece. Princeton: Princeton University Press, 2002.

FURLEY, W. D. and Bremer, J. M. Greek Hymns. 2 vols., Tübingen: Mohr Siebeck, 2001.

FURLEY, W. D. Prayers and Hymns. In OGDEN, D. (ed.). A companion to Greek Religion. Oxford: Oxford University Press, 2007. p. 117-131.

JANKO, R. The Structure of the Homeric Hymns: A Study in Genre. Hermes v. 109, p. 9-24, 1981.

JANKO, R. Homer, Hesiod and the Hymns. Cambridge: Cambridge University Press, 1982.

KOWALZIG, B. Singing for the Gods: Performances of Myth and Ritual in Archaic and Classical Greece. Oxford: Oxford University Press, 2007.

LEDUC, C. Le pseudo-sacrifice d'Hermes. Kernos, v. 18, p. 141-165, 2005.

LÉTOUBLON, F. Commencer à chanter. In BOUCHON, R., BRILLET-DUBOIS, P., WEISSMAN, N. L. M. (eds.). Hymnes de la Grèce Antique: Approches Littéraires et Historiques. Lyon: Maison de l'Orient et de la Méditerranée, 2012. p. 21-36.

LORD, A. B. The Singer of Tales. New York: Harvard University Press, 1960. 
MILLER, A. M. The 'Address to the Delian Maidens' in the Homeric Hymn to Apollo: Epilogue or Transition? TAPhA, v. 109, p. 173-86, 1979.

MILLER, A. M. From Delos to Delphi: A literary Study of the Homeric Hymn to Apollo. Leiden: Brill, 1986.

MORAND, A-F. Études sur les Hymnes orphiques. Leiden: Brill, 2001.

PULLEYN, S. The Power of Names in Classical Religion. CQ, v. 44, p. 17-25, 1994.

PULLEYN, S. Prayer in Greek Religion. Oxford: Oxford University Press, 1997.

RACE, W. H. Aspects of Rhetoric and Form in Greek Hymns. GRBS, v. 23, p. 5-14, 1982.

SHELMERDINE, S. C. Odyssean Allusions in the Fourth Homeric Hymn. TAPhA,v. 116, p. 49-63, 1986.

SILVA BARRIS, J. Metre and Rhythm in Greek Verse. Wien: OAW, 2011.

TORRES-GUERRA, J. B. Sobre la conclusión de los Himnos Homéricos y sus circunstancias de ejecución. Minerva, v. 16, p. 39-44, 2002-2003.

VAN DEN BERG, R. M. Proclus' Hymns: Essays, Translations, Commentary. Leiden: Brill, 2001.

VERGADOS, A. The "Homeric Himn to Hermes". Berlin: De Gruyter, 2013.

VERSNEL, H. S. Religious Mentality in Ancient Prayer. In VERSNEL, H. S. (ed.). Faith, Hope and Worship: Aspects of Religious Mentality in the Ancient World. Leiden: Brill, 1981. p. 1-64. 
